\title{
МОДЕЛЬ ТЕХНОГЕННЫХ ПРОЦЕССОВ НА АСТРАХАНСКОМ ГАЗОКОНДЕНСАТНОМ \\ МЕСТОРОЖДЕНИИ ПО ДАННЫМ ГЕОХИМИЧЕСКИХ ИССЛЕДОВАНИЙ СКВАЖИН
}

Зыкин H.H.

(Всероссийский научно-исследовательский институт природных газов и газовыхх пехнологий (ВНИИГАЗ), лаборатория "Гидрогеологии, геохииии и геоэкологии», Россия, г. Москва)

Проводить контролируемую разработку любого газового месторождения можно только в том случае, когда имеется чёткое представление о геологических, горнотехнических и физико-химических условиях по всему разрабатьваемому разрезу. В отличие от газовых месторождений Западной Сибири, в продуктивном горизонте Астраханского газоконденсатного месторождения (АГКМ) в больших количествах содержатся азот, сероводород, углекислый газ и свободные формы водорода. Данные соединения значительно осложняют процесс разработки. Появление кислых, реакционно-способных и высоко агрессивных водных соединений в межколонном пространстве эксплуатационных скважин может стать причиной аварийных ситуаций, а выход вредных компонентов в атмосферу может неблагоприятно повлиять на экологическую обстановку. Методы диагностики источников межколонных давлений (МКД) и перетоков в заколонных пространствах должны обеспечивать однозначное заключение об интервалах и интенсивности этих явлений, поскольку именно по итогам проведения диагностических исследований определяется схема проведения работ по ограничению развития перетоков и обосновывается возможность безопасной эксплуатации месторождения. В тоже время многие доступные и традиционные методы изучения межколонных водопроявлений на АГКМ являются малоэффективными либо недостаточными. Так установление источннков поступления реакционных компонентов в межколонное пространство скважин по химическому составу флюида, по причине неизученности первоначальных его характеристик, из-за значительных изменений при технологических воздействиях на продуктивный горизонт и нестабильности состава флюида даже в процессе отробования скважин, становится затруднительным.

Наиболее инертным и консервативным параметром сингенетичных с углеводородами флюидов является изотопный состав сопутствующих им вод. С целью выявления источников межколонных давлений в скважинах Астраханского месторождения нами были проведены определения изотопного состава водорода и кислорода $\left(\delta \mathrm{D}\right.$ и $\left.\delta^{18} \mathrm{O}\right)$ воды, доступньг для опробования водопроявлений - потенциальых источников МКД. Также были исследовағіы химические свойства вод (стандартный шестикомпонентный анализ $+\mathrm{J}$ и $\mathrm{Br}$ ).

В результате проведённых работ определены геохимические особенности вод верхнего водонослого горизонта, крупных водотоков района (р.p. Волга, Бузан, Ахтуба), естественных водоёмов на территории месторождения, поверхностных (метеогенных) вод района, исследован химический и изотопный состав вод пермского водоносного горизонта и водоносных горизонтов подсолевого комплекса (среднекаменноугольного продуктивного и верхнедевонского). Для оценки степени техногенных воздействий на геохимические свойства водопроявлений были исследованы пробы попутной воды, получаемой на контрольных сепараторах из продукции эксплуатационных скважин, а также изучен отработанный фильтрат бурового раствора. После исследования геохимических свойств водопроявлений - потенциальных источников МКД, был изучен химический и изотопный состав кислорода и водорода водопроявлений из межколонных пространств некоторых эксплуатационных скважкин месторождения.

Результаты исследований показали значительное отличие геохимических характеристик изученных водопроявлений, при этом установлено, что во́ды и солевого, и подсолевого комплекса по геохимическим свойствам отличны как между собой, так и от вод верхнего гидрогеологического этажа. Исходя из представлений о генетических особенностях вод, изотопный состав воды (рапы) пермского водоносного горизонта близок к среднеокеаническому стандарту, несколько утяжелён относительно SMOW, и, таким образом, отвенает во́дам эвапоритового бассейна. Изотопный состав водорода $(\delta \mathrm{D})$ воды среднекаменноугольного продуктивного горизонта имеет значения, характерные для метеогенных вод очень низких широт. В тоже время, изотопный состав вод продуктивного горизонта показал значительное утяжеление по кислороду (до $+10 \%$, SMOW), что говорит о принадлежности их во́дам закрытых водоёмов (внутриконтинентальных морей) и бо́льшей метаморфизованности вод этого комплекса, по сравнению с рапой пермского горизонта.

При изучения техногенных вод из газовых залежей, в составе которых в заметных количествах присутствовати кислые компоненты, установлено изменение изотопного состава их кислорода и водорода. Таким образом, отклонения изотопного состава попутньх вод от первоначальных характеристик пиастовых вод могут быть использованы для диагностики техногенных процессов при разработке залежей. Полученные данные позволили обосновать возможность использования геохимических свойств водных флюидов в качестве самостоятельного критерия при установлении источников межколонных проявлений.

В результате проведённьх исследований, было установлено, что для части скважин месторождения источником водного фмюида межколоннњ водогроявлений является водоносный горизонт перми, а в части присутствует инфильтрационная вода верхнего гидрогеологического этажа (современная метеогенная вода). 